\title{
Effects of Temperature, Light and Pre-Chilling on Seed Germination of Stevia rebaudiana (Bertoni) Bertoni Accessions
}

\author{
Mario Macchia, Laura Andolfi, Lucia Ceccarini, Luciana G. Angelini” \\ Dipartimento di Agronomia e Gestione dell'Agroecosistema, Università di Pisa \\ Via San Michele degli Scalzi 2, 56124 Pisa, Italy
}

Received: 13 July 2006. Accepted: 18 December 2006

\begin{abstract}
Stevia rebaudiana (Bertoni) Bertoni is a perennial shrub of the Asteraceae family native to Paraguay and Brazil where it has been used for several years as a sweetener. It is a short-day species, with a critical light requirement for flowering of roughly 13 hours. In plants whose biological cycle is strongly photoperiod-dependent, latitude is one of the major factors influencing reproduction. Late flowering may adversely affect seed production if this occurs during a season that is unfavorable to pollination. At Italian latitudes, this species often gives scanty seed production, with low germination rate and poor germination energy of seeds produced. In 2001 four accessions have been grown for seed production in a field plot experiment in Central Italy. The various accessions were found to exhibit noticeably different photoperiod requirements, which affected flowering time (from late August to the end of September) and consequently also the conditions of achene filling and ripening. Late flowering and seed ripening occurred during autumn season, unfavourable to complete seed formation, leading to an increase in the empty seed percentage recorded for each accession. Detailed germination trials were therefore undertaken using seeds collected from plants of the different accessions in order to assess the quality of the seeds produced. Various germination methods have been tested in a controlled environment adopting four different temperatures $\left(20^{\circ} \mathrm{C}, 25^{\circ} \mathrm{C}\right.$ constant temperature and $15 / 25^{\circ} \mathrm{C}, 20 / 30^{\circ} \mathrm{C}(16 / 8 \mathrm{~h})$ alternating temperature) in light or darkness with or without pre-chilling. Germination rates varied over an extensive range (germination percentage from 9 to $83 \%$ ), mainly due to the divergent specific characteristics of the material examined and the different treatments studied. At all temperatures tested, the most earlier accession, showed the higher germination percentages (54-83\%) while the latest accession was among those with the lowest germination values (9-44\%). Overall, at the constant temperatures assayed, pre-chilling gave a higher germination percentage as compared to no pre-chilling, while at alternating temperatures higher germination rates were obtained in the absence of pre-chilling. The great variability observed between accessions for photoperiodic requirement as well as in seed germinative characteristics was probably due to the fact that this species was not subjected to any genetic improvement program.
\end{abstract}

Key-words: natural sweetener, germination requirements, Stevia rebaudiana Bert.

\section{Introduction}

The major problems encountered in growing medicinal and aromatic plants concern not only the difficulty in acquiring useful information on the most modern and rational cultural and technological practices, but also, for many species, the more concrete difficulty in obtaining qualitatively valid propagation material. Vegetative propagation methods are of aid in producing plants with biochemical and agronomic characteristics that will remain constant over time, but some of these techniques (such as micro-propagation) are still very costly. However, they may be particularly useful for species originating from climatic environments that differ markedly from the Mediterranean area, where such species may be unable to complete their reproductive cycle.

Stevia rebaudiana is a perennial shrub of the Asteraceae (Compositae) family native to the mountain plateau of Paraguay $\left(25^{\circ}-26^{\circ}\right.$ latitude South). Its leaves contain a large number of sweet constituents represented by diterpenic 
and tetracyclic glycosides. Among these, stevioside and rebaudioside $\mathrm{A}$ have been assessed to be, respectively, 300 and 450 times sweeter than sucrose but they are noncaloric (Bridel and Lavieille, 1931; Soejarto et al., 1983; Hussain et al., 1988; Nardi, 1996). Therefore, Stevia rebaudiana has become popular as a sweetener in Asia and South America and has been used a dietary supplement in the United States (Geuns, 2003). Today it is grown in many parts of the planet for production of natural sweeteners.

The leaves can be harvested in a single cutting prior to flowering, but it is also possible to plan two cuttings a year (Ruta et al., 1999).

Stevia rebaudiana responds positively to photoperiod stimulation (short-day flowering). It is self-incompatible, and thus needs entomophilic pollination (Handro et al., 1989). The fruit is an achene with a pappus, consisting of 13-15 appendices. The presence of the pappus and the extremely small size of the achene (weight of 1000 seeds 0.15-0.29 g) (Carneiro, 1990) facilitate wind-borne dispersal.

Seed production is influenced by the number of inflorescences per surface area unit, and thus by planting density, and also by the period when the last stem cutting is performed. Carneiro (1990) observed that the greatest quantity of flowers was obtained about 130 days after leaf harvesting, giving seed production of roughly $8 \mathrm{~kg} / \mathrm{ha}^{-1}$ as compared to a yield of roughly $3 \mathrm{~kg} / \mathrm{ha}^{-1}$ if seeds were collected 60 days after the final leaf cutting. Furthermore, Carneiro (1990) showed that greatest yield of pure and viable seed was achieved with a density of 80.000 plants ha ${ }^{-1}$, field grown in double rows with inter-row spacing of 35 and $65 \mathrm{~cm}$ respectively.

Regulations in Brazil state that seed batches are approved for release on the market if impurities (represented by other seeds and inert material) do not exceed 5\% of total batch weight. Harvested material includes many empty seeds, easily recognizable by their light color. These are considered as inert material (AA.VV., 1980). Seed viability and production are known to be closely linked to the plant's developmental conditions during pollination and seed ripening, and to climatic conditions prevailing during these two stages (Castellano, 1981).

The technological procedure of seed selec- tion involves elimination of the pappus, partly in order to provide a more extensive surface for contact between the seed and the germination substrate, but also to reduce the risk of pathogen development during germination, as the shape of the appendices allows fungal spores to collect on their surface. However, mechanical elimination of the pappus may cause an increase in number of abnormal plantlets, with rootlets that are stunted or dark at the apex and cotyledons separated from the growing tip (Carneiro, 1990).

The seeds are photoblastic positive (Brandle et al., 1998). In the literature, available data on the most suitable germination-inducing temperatures are discordant: while Carneiro (1990) found the optimum to be a fixed temperature of $25^{\circ}$ C, Sakaguchi and Kan (1982) found a greater optimum temperature range $\left(15-30^{\circ} \mathrm{C}\right)$.

Germination tests conducted on seeds preserved with different techniques showed that in order to extend seed viability from a few months to more than three years, the optimal preservation method is to store seeds in insulating containers maintained at low temperature $\left(-10^{\circ} \mathrm{C},-18^{\circ} \mathrm{C}\right)$ (Shuping and Shizhen, 1995).

Within the framework of current knowledge as outlined above, the aim of this study was to analyze the seed production stage and seed qualitative characteristics in some accessions of Stevia rebaudiana grown in the temperate climate of central Italy. Attention focused on presence of empty seeds and seed weight, and on testing different germination methods in order to identify optimal light and temperature conditions.

\section{Materials and methods}

\subsection{Field plot experiment}

Five accessions were examined: B1, B2, B3 (originating from Brazil) and P1, P2 (from Paraguay). With the exception of $\mathrm{P} 2$, seeds were collected from micro-propagated plants grown in field plots at the experimental Centre of the Dipartimento di Agronomia e Gestione dell'Agroecosistema (S. Piero a Grado, Pisa, Central Italy; $\left.43^{\circ} 40^{\prime} \mathrm{N}, 1^{\circ} 19^{\prime} \mathrm{E}\right)$. P2 seed was sent directly from Paraguay in the summer 2001 and comes from plants grown in their native environment. The germinative characteristics of this seed sample (P2) were compared with those of 
$\mathrm{B} 1, \mathrm{~B} 2, \mathrm{~B} 3$ and $\mathrm{P} 1$ accessions grown under temperate climatic conditions. Soil was a typical Xerofluvent of the low Arno river plain, characterized by a superficial water table $120 \mathrm{~cm}$ deep in dry conditions. Its physical and chemical characteristics were: sand $59.8 \%$; loam $33.8 \%$; clay $6.4 \%$; organic matter $1.43 \%$; total $\mathrm{N} 0.77 \mathrm{~g} \mathrm{~kg}^{-1}$; available P $4.9 \mathrm{mg} \mathrm{kg}^{-1}$ (Olsen method); exchangeable K $183.58 \mathrm{mg} \mathrm{kg}^{-1}$ (Dirks Schepper method); $\mathrm{CaCO}_{3} 1.44 \% ; \mathrm{pH}$ 8.19. The water table was rather superficial even in summer. The previous crop was barley (Hordeum vulgare L.). The soil tillage was conducted in the autumn of 2000 and consisted of medium-depth ploughing (0.3-0.4 m). Seedbed preparation was conducted in the spring, immediately before planting, by a double-disking harrow and a field cultivator.

Planting was carried out on 4 May 2001 using $0.1 \mathrm{~m}$ tall micro-propagated one-year-old plants obtained from B1, B2, B1 and P1 selected mother plants and maintained in greenhouse until transplanting began. Plants were watered immediately after planting $\left(20 \mathrm{~m}^{3} \mathrm{ha}^{-1}\right)$ to facilitate post-transplanting recovery. Plants were grown at 0.30 and $0.50 \mathrm{~m}$ intra- and inter-row spacing respectively, at a population of 70,000 plants per hectare. Pre-plant fertilizer was broadcasted at a rate of $100 \mathrm{~kg} \mathrm{P}^{-1}$ (triple super-phosphate) and $100 \mathrm{~kg} \mathrm{~K} \mathrm{ha}^{-1}$ (potassium sulphate). Nitrogen fertilizer (urea) was applied at a rate of $100 \mathrm{~kg} \mathrm{ha}^{-1}$ as $50 \%$ pre-plant and $50 \%$ side dressing when $S$. rebaudiana plants were $0.30 \mathrm{~m}$ tall. The field plots were kept weedfree by hoeing.

The experimental design was a randomized block design replicated four times. Plots measured $10 \mathrm{~m}^{2}$ each. Plants were kept well irrigated during spring and summer, water being delivered daily by an automated drip irrigation system equipped with a pressure-compensated and non-leakage dripper line. Seeds from the four accessions were harvested during November on several occasions. The seeds were conserved in controlled conditions at $5^{\circ} \mathrm{C}$ and $50 \%$ relative humidity, until the beginning of the germination test ( 5 months after harvest).

\subsection{Germination experiments}

To ensure accurate characterization of the various accessions, weight of 1000 seeds was examined according to ISTA rules (ISTA, 2001), and the proportion of full to empty seeds recorded.

Germination tests were conducted at the DAGA - LaRAS (Dipartimento di Agronomia e Gestione dell'Agroecosistema - Laboratorio di Ricerca ed Analisi sulle Sementi) using 150 $\mathrm{mm}$ diameter Petri dishes moistened with $5 \mathrm{ml}$ Thyram solution at a concentration of $0.2 \mathrm{~g}$ per $500 \mathrm{ml}$ distilled water. The filter paper substrate was maintained moist by periodic addition of distilled water. To reduce water loss to a minimum, dishes were wrapped in transparent polyethylene bags.

S. rebaudiana is not contemplated by the International Rules for Seed Testing (ISTA, 2005) and we have therefore attempted to develop a germination protocol for this species. For this reason the first test was carried out by placing the Petri dishes in a heat-controlled cabinet at alternating temperature of $20 / 30^{\circ} \mathrm{C}(16 / 8 \mathrm{~h})$ and light (16/8h dark/light) conditions. This temperature regime was adopted taking into account the germination requirements of closely related members of Asteraceae Family. The light was provided by cool white-light fluorescent lamps (Osram L18 W/20, $10 \mu \mathrm{mol}$ photons $\mathrm{s}^{-1} \mathrm{~m}^{-2}$ photosynthetically active radiation). A randomized block design was used to compare the different accessions under $20 / 30^{\circ} \mathrm{C}$ alternating temperature.

The second test was realised in order to study the influence of temperature, light and pre-chilling and their interaction on germination. For each accession, four different heat regimes $\left[20^{\circ} \mathrm{C}\right.$ and $25^{\circ} \mathrm{C}$ constant temperature and $15 / 25^{\circ} \mathrm{C}, 20 / 30^{\circ} \mathrm{C}(16 / 8 \mathrm{~h})$ alternating temperature] were adopted. These regimes were singled out as those giving the highest germination rate, after a preliminary analysis of germination at a wide range of temperatures (from $15^{\circ} \mathrm{C}$ to $35^{\circ} \mathrm{C}$ ) (Marcello, 1994). Germination tests were then conducted in continuous light supplied by cool white-light fluorescent lamps (Osram L18 W/20, 10 umol photons $\mathrm{s}^{-1} \mathrm{~m}^{-2}$ photosynthetically active radiation) and in darkness. To avoid possible primary dormancy phenomena, seeds were pre-chilled at $5^{\circ} \mathrm{C}$ in dark for 7 days. After the pre-chilling treatment, seeds were transferred to a germination cabinet adopting the same temperatures and light or dark conditions.

A 4-factor experimental design was used for 
each accession to test the effects of accessions (B1, B2, B3, P1, P2), temperature $\left(20^{\circ} \mathrm{C} ; 25^{\circ} \mathrm{C}\right.$; $15 / 25^{\circ} \mathrm{C}$ and $20 / 30^{\circ} \mathrm{C}$ ), Pre-chilling $(\mathrm{P}=$ Prechilling; NP = No Pre-chilling), Light/Dark ( $\mathrm{L}=$ Light; D = Dark), and their interactions. For each treatment, three replications of 100 seeds were made. Tests had a mean duration of 15 days, during which the number of germinated seeds was counted. Seeds were considered germinated when the rootlet reached the length of the seed itself. Germination energy was also evaluated by calculating Mean Germination Time (MGT) using the formula of Ellis et al. (1981).

\subsection{Statistical Analysis}

For each experiment all variables were analyzed by ANOVA using different experimental designs. A standard randomized block design was used to compare the four different Stevia rebaudiana accessions in the field trials and the seed germination characteristics in the first test. A 4-factor experimental design was used to test the effects of accession (A), temperature (T), pre-chilling $(\mathrm{P})$, light regime $(\mathrm{L})$ and their reciprocal interactions. Percentage data were arcsine transformed before ANOVA according to the Bliss formula (Bliss, 1937).

Significantly different means were separated at 0.05 and 0.01 probability level by the Least Significant Difference (LSD) test (Gomez and Gomez, 1984).

\section{Results and discussion}

\subsection{Weather conditions}

During the 2001 average air temperatures increased from March to August. Summer 2001 was a particularly hot season with mean sum- mer air temperatures of $29.7^{\circ} \mathrm{C}$, which were higher than the typical long period temperature $\left(28.1^{\circ} \mathrm{C}\right)$. From September to November the minimum air temperatures never decreased below $13^{\circ} \mathrm{C}$, and maximum values remained above $25^{\circ} \mathrm{C}$. From December to February air temperature never dropped below $0^{\circ} \mathrm{C}$.

Summer 2001 was a particularly dry season, with $18.1 \mathrm{~mm}$ rainfall from July-August, which was below the 1918-1982 long-term data for the same location $(67 \mathrm{~mm})$. Lower annual rainfall than long-term average values was also observed. However, rainfall during September was higher than usual while October and November were characterized by high rainfall as typical for the area.

\subsection{Seed production and quality}

Plants belonging to accessions B1, B2, B3 and P1 showed scalar flowering. P1 was the earliest flowering population, achieving full flowering by the end of August. Flowering of accessions B2, B1 and B3 followed, in that order, at roughly 10 day intervals from each other. As a result of the late flowering, climatic conditions were already characterized by heavy rainfall and low temperatures when seed production took place. Such conditions were particularly unfavourable to pollination and above all to seed filling and ripening, as well as creating difficulties for harvesting operations. Consequently, a greater number of empty seeds were observed in lateflowering than early-flowering ones (Table 1). B3 that flowered up to about 2 months after the earlier one (P1), showed empty seeds amount three-fold greater than P1.

Seeds from the various accessions were of different sizes, showing statistically significant differences (Table 1). Thus accessions B1 and P2

Table 1. Weight per 1000 seeds, flowering date, empty seed percentage, germination and mean germination time in the examined accessions.

\begin{tabular}{lccccc}
\hline Accessions & $\begin{array}{c}\text { Weight per } \\
1000 \text { seeds }(\mathrm{g})\end{array}$ & Flowering date & Empty seeds (\%) & $\begin{array}{c}\text { Mean germination } \\
\dagger \dagger(\%)\end{array}$ & $\begin{array}{c}\text { Mean Germination } \\
\text { Time }{ }^{\dagger \dagger}(\text { days })\end{array}$ \\
\hline B1 & $0.264 \mathrm{~A}$ & 20 September & $51 \mathrm{~b}$ & $42.5 \mathrm{C}$ & 5.68 \\
$\mathrm{~B} 2$ & $0.207 \mathrm{~B}$ & 10 September & $37 \mathrm{c}$ & $54.5 \mathrm{~B}$ & 5.52 \\
$\mathrm{~B} 3$ & $0.197 \mathrm{~B}$ & 29 October & $79 \mathrm{a}$ & $17.5 \mathrm{E}$ & 5.71 \\
P1 & $0.208 \mathrm{~B}$ & 28 August & $25 \mathrm{~d}$ & $72.5 \mathrm{~A}$ & 4.64 \\
P2 & $0.237 \mathrm{~A}$ & n.d. & n.d. & $22.5 \mathrm{D}$ & 6.67 \\
\hline
\end{tabular}

Mean values followed by different letters are different at $\mathrm{P} \leq 0.01$ according to LSD test.

${ }^{\dagger}$ n.d. = not determined;

${ }^{\dagger \dagger}=$ Germination test at $20 / 30{ }^{\circ} \mathrm{C}$. 
produced the heaviest seeds, but seeds of other accessions, although lighter in weight, still fell within the 0.15-0.29 g range indicated by Carneiro (1990). No significant correlation was found between germination percentage and seed weight.

Results obtained from the first experiment with an alternating temperature $\left(20 / 30^{\circ} \mathrm{C}\right)$ regime revealed statistically significant differences in germination percentages between the accessions (Tab. 1). Highest germinated seed percentage was observed in accession P1 (73\%), followed in decreasing order by B2 (55\%), B1 (43\%), P2 (23\%), and B3 (18\%). The very low germination rate observed in this last accession, of Brazilian origin, could be due to the fact that it showed extremely late flowering, and therefore the seed formation and ripening stage occurred during highly adverse climatic conditions (very wet weather and drop in temperature). However, mean germination time in this first experiment showed no significant differences among the accessions examined, with a duration of roughly 6 days (Tab. 1). A correlation analysis between flowering date, empty seed and germination percentage, was performed (Figure 1). The seed quality decreased linearly as flowering delayed. Germination percentage decreased about $9 \%$ every 10 days of flowering delay from the end of August and concurrently empty seed content increased 10\% (Fig. 1).

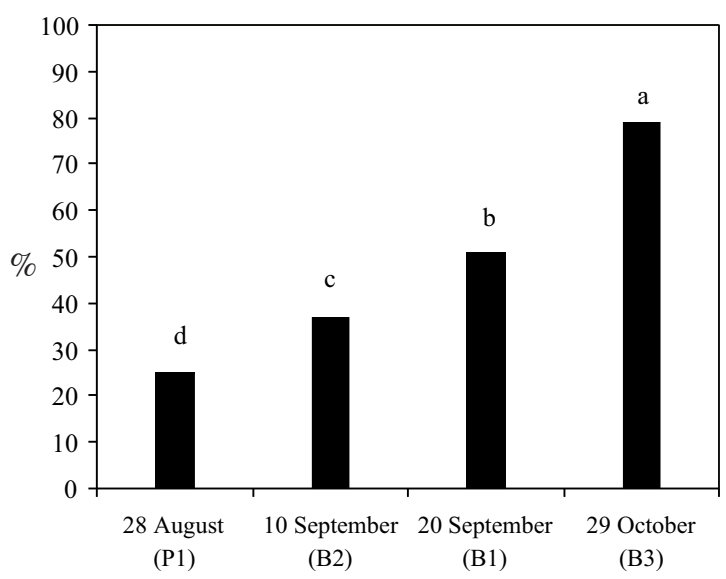

Flowering date (Accessions)

Figure 1. Empty seed percentages in the different Stevia rebaudiana accessione in relation to the different full flowering dates.

Mean values followed by different letters are different at $\mathrm{P}<0.05$ according to LSD test.

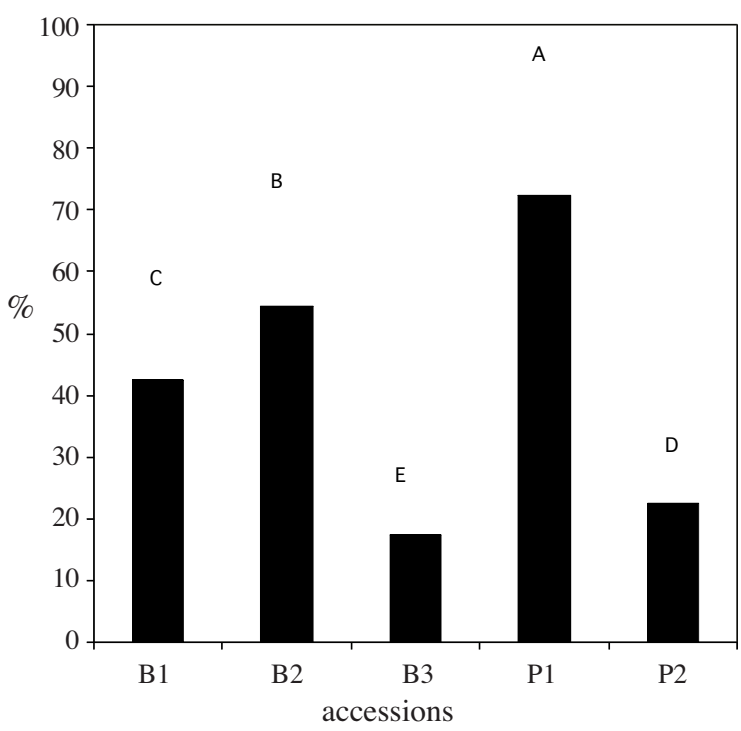

Figure 2. Mean germination percentages in the different Stevia rebaudiana accessions. Germination test at $20 / 30^{\circ} \mathrm{C}$.

Mean values followed by different letters are different at $\mathrm{P}<0.01$ according to LSD test.

The types of treatment adopted in the second experiment for the various accessions, namely different accessions (A), heat regimes $(\mathrm{T})$, chilling or no pre-chilling $(\mathrm{P})$, presence or absence of light (L) and their interactions, gave statistically significant differences (Tab. 2). Some treatments significantly influenced both germination rate and germination energy. The

Table 2. Summary of analysis of variance of the germination percentages and Mean Germination Time values of Stevia rebaudiana accessions.

\begin{tabular}{lrc}
\hline Source & $\begin{array}{c}\text { Germination (\%) } \\
\text { (Mean square) }\end{array}$ & $\begin{array}{c}\text { Mean Germination } \\
\text { Time (days) } \\
\text { (Mean square) }\end{array}$ \\
\hline Accessions (A) & $14095.837 * * *$ & $16.777 * * *$ \\
Temperature (T) & $108.625 * * *$ & $12.581^{* * *}$ \\
Pre-chilling (P) & $75.625 * * *$ & $133.956 * * *$ \\
Light (L) & $189.225 * * *$ & $7.413 * * *$ \\
AxT & $187.521 * * *$ & $1.519 * * *$ \\
AxP & $76.063 * * *$ & $2.777 * * *$ \\
TxP & $163.092^{* * *}$ & $0.374 * * *$ \\
AxL & $70.038^{* * *}$ & $1.573 * * *$ \\
TxL & $4.825 * * *$ & $0.894 * * *$ \\
PxL & $1.225 \mathrm{NS}$ & $6.839 * * *$ \\
AxTxL & $76.388^{* * *}$ & $1.080^{* * *}$ \\
AxTxP & $21.779 * * *$ & $0.542 * * *$ \\
AxPxL & $44.163 * * *$ & $0.557 * * *$ \\
TxPxL & $199.758^{* * *}$ & $0.933 * * *$ \\
AxTxPxL & $90.613 * * *$ & $0.395 * * *$ \\
\hline
\end{tabular}

*** Significant at $\mathrm{P}=0.001$.

NS non-significant. 
Table 3. Mean germination percentages in each accession as results of the interaction between temperature, pre-chilling and light treatments.

\begin{tabular}{|c|c|c|c|c|c|c|c|c|}
\hline & Pre-chilling & & & & Pre-ch & & & \\
\hline $\begin{array}{c}\text { Temperature } \\
\left({ }^{\circ} \mathrm{C}\right)\end{array}$ & $\begin{array}{l}\text { Light } \\
(\%)\end{array}$ & & $\begin{array}{c}\text { Dark } \\
(\%)\end{array}$ & & $\begin{array}{c}\text { Light } \\
(\%)\end{array}$ & & $\begin{array}{c}\text { Dark } \\
(\%)\end{array}$ & \\
\hline B1 & & & & & & & & \\
\hline 20 & 34 & $\mathrm{BC}$ & 34 & $\mathrm{BC}$ & 32 & $\mathrm{C}$ & 32 & $\mathrm{C}$ \\
\hline 25 & 30 & $\mathrm{CD}$ & 28 & $\mathrm{D}$ & 38 & $\mathrm{~B}$ & 32 & $\mathrm{C}$ \\
\hline $15 / 25$ & 22 & $\mathrm{E}$ & 32 & $\mathrm{C}$ & 38 & $\mathrm{~B}$ & 28 & $\mathrm{D}$ \\
\hline $20 / 30$ & 24 & $\mathrm{DE}$ & 22 & $\mathrm{E}$ & 22 & $\mathrm{E}$ & 42 & A \\
\hline Mean & 28 & & 29 & & 33 & & 34 & \\
\hline B2 & & & & & & & & \\
\hline 20 & 42 & $\mathrm{G}$ & 57 & $\mathrm{CD}$ & 49 & $\mathrm{E}$ & 48 & $\mathrm{EF}$ \\
\hline 25 & 44 & $\mathrm{FG}$ & 47 & $\mathrm{EF}$ & 58 & $\mathrm{C}$ & 45 & $\mathrm{~F}$ \\
\hline $15 / 25$ & 56 & $\mathrm{CD}$ & 62 & B & 66 & A & 60 & $\mathrm{BC}$ \\
\hline $20 / 30$ & 61 & B & 42 & $\mathrm{G}$ & 62 & B & 54 & $\mathrm{D}$ \\
\hline Mean & 51 & & 52 & & 59 & & 52 & \\
\hline B3 & & & & & & & & \\
\hline 20 & 44 & A & 24 & $\mathrm{C}$ & 19 & DE & 24 & $\mathrm{C}$ \\
\hline 25 & 23 & $\mathrm{CD}$ & 20 & $\mathrm{D}$ & 24 & $\mathrm{C}$ & 18 & $\mathrm{DE}$ \\
\hline $15 / 25$ & 16 & $\mathrm{E}$ & 25 & $\mathrm{C}$ & 28 & $\mathrm{~B}$ & 15 & $\mathrm{E}$ \\
\hline $20 / 30$ & 27 & $\mathrm{BC}$ & 9 & $\mathrm{~F}$ & 20 & $\mathrm{D}$ & 17 & $\mathrm{E}$ \\
\hline Mean & 28 & & 20 & & 23 & & 19 & \\
\hline $\mathrm{P} 1$ & & & & & & & & \\
\hline 20 & 70 & $\mathrm{D}$ & 64 & $\mathrm{E}$ & 62 & $\mathrm{E}$ & 54 & $\mathrm{~F}$ \\
\hline 25 & 79 & B & 73 & $\mathrm{C}$ & 74 & $\mathrm{BC}$ & 83 & A \\
\hline $15 / 25$ & 67 & $\mathrm{DE}$ & 65 & $\mathrm{E}$ & 70 & $\mathrm{D}$ & 73 & $\mathrm{C}$ \\
\hline $20 / 30$ & 62 & $\mathrm{E}$ & 73 & $\mathrm{C}$ & 72 & $\mathrm{CD}$ & 72 & $\mathrm{CD}$ \\
\hline Mean & 69 & & 69 & & 70 & & 71 & \\
\hline $\mathrm{P} 2$ & & & & & & & & \\
\hline 20 & 23 & $\mathrm{C}$ & 17 & $\mathrm{D}$ & 19 & $\mathrm{CD}$ & 25 & $\mathrm{C}$ \\
\hline 25 & 24 & $\mathrm{C}$ & 20 & CD & 21 & $\mathrm{CD}$ & 18 & $\mathrm{D}$ \\
\hline $15 / 25$ & 29 & B & 28 & $\mathrm{BC}$ & 35 & A & 21 & $\mathrm{CD}$ \\
\hline $20 / 30$ & 21 & $\mathrm{CD}$ & 17 & $\mathrm{D}$ & 21 & $\mathrm{CD}$ & 22 & $\mathrm{CD}$ \\
\hline Mean & 24 & & 21 & & 24 & & 22 & \\
\hline
\end{tabular}

Mean values followed by different letters are significantly different at $\mathrm{P} \leq 0.01$ according to LSD test.

accessions B2, B3 and P2 showed significant higher germination values in light than in dark while on the contrary, B1 showed significantly highest germination values in dark. Regarding pre-chilling, only the seed of B3, the latest flowering accession, were induced to germinate by pre-chilling. This treatment promotes the germination by reducing the dormancy for the not complete maturation of the seed produced under unfavourable conditions.

Furthermore, interaction among treatments led to statistically significant differences in results achieved with the various accessions. Thus mean data on the interaction TxPxL (Tab. 3) showed that in population B1 the greatest number of germinated seeds ( $42 \%)$ was obtained in the treatment adopting $20 / 30^{\circ} \mathrm{C}$ alternating temperature, absence of light and pre-chilling. In contrast, the other Brazilian accession (B2) gave better results with lower temperatures, achieving its highest percentage of germinated seeds $(66 \%)$ with an alternating temperature of $15 / 25^{\circ} \mathrm{C}$ in presence of light and without prechilling. Population B3 differed from both these accessions in achieving the highest germination percentage $(44 \%)$ at a constant temperature of $20^{\circ} \mathrm{C}$, in presence of light and pre-chilling.

For the other two accessions, P1 and P2, the highest germination percentage was observed in the no pre-chilling treatment, but they were distinguished from each other by their different response to the heat regime and to presence or absence of light. Thus for accession P1, highest germination percentage was obtained at $25^{\circ} \mathrm{C}$ 
Table 4. Mean Germination Time (MGT in days) of each accession as results of the interaction between temperature, pre-chilling and light treatments.

\begin{tabular}{|c|c|c|c|c|c|c|c|c|}
\hline & Pre-chilling & & & & Pre-chi & & & \\
\hline $\begin{array}{c}\text { Temperature } \\
\left({ }^{\circ} \mathrm{C}\right)\end{array}$ & $\begin{array}{l}\text { Light } \\
(\%)\end{array}$ & & $\begin{array}{c}\text { Dark } \\
(\%)\end{array}$ & & $\begin{array}{l}\text { Light } \\
(\%)\end{array}$ & & $\begin{array}{c}\text { Dark } \\
(\%)\end{array}$ & \\
\hline B1 & & & & & & & & \\
\hline 20 & 4.23 & $\mathrm{BC}$ & 5.47 & $\mathrm{D}$ & 6.62 & $\mathrm{E}$ & 6.87 & $\mathrm{EF}$ \\
\hline 25 & 5 & $\mathrm{CD}$ & 3.21 & A & 6.05 & $\mathrm{D}$ & 5.50 & $\mathrm{D}$ \\
\hline $15 / 25$ & 4 & B & 4 & $\mathrm{~B}$ & 3.95 & B & 5.64 & $\mathrm{D}$ \\
\hline $20 / 30$ & 4.58 & $\mathrm{C}$ & 4 & $\mathrm{~B}$ & 7.18 & $\mathrm{~F}$ & 6.96 & $\mathrm{EF}$ \\
\hline Mean & 4.45 & & 4.17 & & 5.95 & & 6.24 & \\
\hline B2 & & & & & & & & \\
\hline 20 & 4.14 & $\mathrm{D}$ & 3.12 & A & 5.37 & $\mathrm{H}$ & 5.73 & $\mathrm{H}$ \\
\hline 25 & 3.32 & A & 3.17 & A & 5.10 & $\mathrm{G}$ & 6.55 & $\mathrm{~L}$ \\
\hline $15 / 25$ & 3.85 & $\mathrm{C}$ & 3.37 & $\mathrm{~B}$ & 4.89 & FG & 5.93 & I \\
\hline $20 / 30$ & 4.49 & $\mathrm{E}$ & 4.76 & $\mathrm{~F}$ & 5.84 & I & 6.98 & $\mathrm{M}$ \\
\hline Mean & 3.95 & & 3.6 & & 5.3 & & 6.25 & \\
\hline B3 & & & & & & & & \\
\hline 20 & 5.25 & G & 4.26 & $\mathrm{D}$ & 6.42 & M & 6.58 & $\mathrm{~N}$ \\
\hline 25 & 3.26 & B & 3.95 & $\mathrm{C}$ & 4.70 & $\mathrm{~F}$ & 5.61 & I \\
\hline $15 / 25$ & 3.31 & B & 2.8 & A & 4.46 & $\mathrm{E}$ & 5.20 & $\mathrm{G}$ \\
\hline $20 / 30$ & 4.81 & $\mathrm{~F}$ & 5.4 & $\mathrm{H}$ & 6.05 & $\mathrm{~L}$ & 6.58 & $\mathrm{~N}$ \\
\hline Mean & 4.15 & & 4.11 & & 5.4 & & 5.99 & \\
\hline $\mathrm{P} 1$ & & & & & & & & \\
\hline 20 & 4.21 & $\mathrm{E}$ & 5.06 & $\mathrm{G}$ & 6.58 & $\mathrm{M}$ & 7.70 & $\mathrm{~N}$ \\
\hline 25 & 2.37 & A & 2.76 & B & 4.24 & $\mathrm{E}$ & 8.15 & $\mathrm{O}$ \\
\hline $15 / 25$ & 2.65 & B & 2.43 & A & 4.34 & $\mathrm{~F}$ & 5.57 & I \\
\hline $20 / 30$ & 3.19 & $\mathrm{C}$ & 3.9 & D & 5.44 & $\mathrm{H}$ & 6.04 & $\mathrm{~L}$ \\
\hline Mean & 3.11 & & 3.52 & & 5.13 & & 6.87 & \\
\hline $\mathrm{P} 2$ & & & & & & & & \\
\hline 20 & 6.08 & D & 5.76 & $\mathrm{C}$ & 7.36 & I & 7.20 & $\mathrm{H}$ \\
\hline 25 & 5.58 & B & 6.25 & $\mathrm{E}$ & 5.71 & $\mathrm{C}$ & 7.72 & $\mathrm{~L}$ \\
\hline $15 / 25$ & 4.75 & A & 6.36 & $\mathrm{EF}$ & 6.45 & $\mathrm{~F}$ & 7.28 & $\mathrm{HI}$ \\
\hline $20 / 30$ & 6.04 & $\mathrm{D}$ & 6.41 & $\mathrm{~F}$ & 7.19 & $\mathrm{H}$ & 7.04 & $\mathrm{G}$ \\
\hline Mean & 5.61 & & 6.18 & & 6.68 & & 7.3 & \\
\hline
\end{tabular}

Mean values followed by different letters are significantly different at $\mathrm{P} \leq 0.01$ according to LSD test.

constant temperature in the absence of light $(83 \%)$, while for $\mathrm{P} 2$ the highest germination rate was obtained with alternating temperature (15$25^{\circ} \mathrm{C}$ ) in presence of light (35\%) (Tab. 3). The seed of P2 and B2 showed similar germination requirements with highest germination values at $15 / 25^{\circ} \mathrm{C}$ in light without pre-chilling.

In all accessions, germination energy, expressed as mean germination time, was also influenced, to a statistically significant extent, by the treatments adopted (Tab. 2 and 4). The best conditions to obtain high germination values do not mach with those to obtain the faster rate of the germination process. In fact germination percentages without pre-chilling were in general enhanced (exception given by B3) while pre- chilling led to shorter mean germination time in all cases as compared to the no-pre-chilling treatment (Tab. 4). In all accessions, the darkness and no pre-chilling treatment led to the longest mean germination time, with a duration of 6-7 days. The best conditions to have fastest germination rate are with pre-chilling in dark with $25^{\circ} \mathrm{C}$ (for B1 and B2) or $15 / 25^{\circ} \mathrm{C}$ (B3 and $\mathrm{P} 1)$ while for $\mathrm{P} 2$ with pre-chilling, in light with 15/25 $\mathrm{C}$ (Tab. 4).

\section{Conclusions}

The different Stevia accessions grown in the temperate climate of Central Italy were able to flower and complete the seed formation and ripening stage, albeit with considerable vari- 
ability. The various accessions were found to exhibit noticeably different photoperiod requirements, which affected flowering time (from late August to the end of September) and consequently also the conditions of achene filling and ripening. Therefore the quantity of empty seeds in the harvested seed batches varied depending on the accession, with a positive relation between flowering time and percentage of empty seeds observed in the given accession. But despite the elevated empty seed amount, filled and well formed seeds in the various batches presented unit weight values comparable to those observed for the respective accessions in their native environment (Carneiro, 1990).

At all temperatures tested, accession P1 presented the highest germination percentage, with values only occasionally dropping below $70 \%$. Accessions B3 and P2 were among those with the lowest germination values: thus for B3 the highest value was $44 \%$, reached at $20^{\circ} \mathrm{C}$ in presence of light after pre-chilling, while P2 had a maximum germination rate of $35 \%$, achieved at the alternating temperature of $15-25^{\circ} \mathrm{C}$ in presence of light without pre-chilling.

Overall, at the constant temperatures assayed, pre-chilling gave a higher germination percentage as compared to no pre-chilling, while at alternating temperatures higher germination rates were obtained in the absence of prechilling.

The problems affecting the germination characteristics of $S$. rebaudiana are partly attributable to the seed health conditions, which depend partly on whether the given accession is early or late flowering. In some of the late flowering accessions, seed ripening may take place during periods particularly suited to the development of pathogens, which may then exert a negative effect on germination.

Finally, the great variety observed by analysis of our data shows that this species is characterized by "natural" populations not subjected to any genetic improvement program. These populations still express an elevated degree of tolerance of difficult conditions accompanied by good adaptability to the environment in which they are introduced. This characteristic will be positively exploited for the genetic improvement work currently in progress within our research group.

\section{References}

AA.VV. 1980. Brasil. Ministério da Agricultura: Regras para analise de sementes. Brasilia, $188 \mathrm{p}$.

Bliss C.I. 1937. Plant Protection (Leningrad), 12, 67.

Brandle J.E., Starratt A.N., Gijzen M. 1998. Stevia rebaudiana: its agricultural, biological, and chemical properties. Canadian Journal of Plant Science, 78:527536.

Bridel M., Lavieille R. 1931. The sweet principle of Kaahe-e (Stevia rebaudiana). J. Pharm. Clin., 14:99-154.

Carniero J.W. 1990. Stevia rebaudiana (Bert.) Bertoni. M.Sc. Thesis, State University of Maringa, Brazil.

Castellano B. 1981. Finalmente una notizia dolce che anche i diabetici potranno assaporare. Erboristeria Domani, 47-53.

Ellis R.H., Roberts E.H. 1981. Towards a rational basis for testing seed quality. In: Seed Production, 605-635. Hebblethwaite, Butterworth London.

Geuns J. 2003. Molecules of interest Stevioside. Phytochemistry, 64:913-921.

Gomez K.A., Gomez A.A. 1984. Statistical procedures for agricultural research. John Wiley \& Sons Ed., New York, $680 \mathrm{pp}$.

ISTA, 2001. International rules of seed testing. Edition 2001 International Seed Testing Association.

Handro W., Ferreira C.M. 1989. Stevia rebaudiana (Bert.) Bertoni: Production of natural sweeteners. Biotechnology in Agriculture and Forestry, 7:468-487.

Hussain R.A., Kinghorn A.D., Soejarto D.D. 1988. Sweetening agents of plant origin: Literature search for candidate sweet plants. Economic Botany, 42(2).

Marcello S. 1994. Stevia rebaudiana Bert.: Caratteristiche biologico-riproduttive e analisi quantitative dei glicosidi. Laurea Degree, Faculty of Agricultural Sciences, University of Pisa, 84 pp.

Nardi U. 1996. Stevia rebaudiana: analisi su un dolcificante naturale. Erboristeria Domani, 6.

Ruta C., De Mastro G., Fortunato I.M., Marzi V. 1999. Modalità di propagazione e tecniche di coltivazione di Stevia rebaudiana Bertoni. Proceedings $33^{\text {rd }}$ Annual Conference of Italian Society for Agronomy, 20-23 September, Agripolis (PD), Italiy, 310-311.

Sakaguchi M., Kan T. 1982. As pesquisas japoneas com Stevia rebaudiana (Bert.) Bertoni e o esteviosido. Ciencia e Cultura, Sào Paulo, 34:235-48.

Shuping C., Shizhen S. 1995. Study on storage tecnique of Stevia rebaudiana seed. Acta Agronomica Sinica, 21(1).

Soejarto D.D., Compadre C.M., Medon P.J., Kamath S.K., Kinghorn A.D. 1983. Potential sweetening agents of plant origin. II. Field search for sweet-tasting stevia species. Economic Botany, 37:71-79. 